\title{
The Longest Eyelash; A Significantly Neglected Finding
}

\author{
Ahmed A Elmassry ${ }^{1 *}$, Mahmoud A Abdelaati ${ }^{1}$ and Mohamed A Elmassry ${ }^{2}$ \\ ${ }^{1}$ Department of Ophthalmology, Alexandria University, Egypt \\ ${ }^{2}$ Department of Ophthalmology, Port-Said University, Egypt
}

Submission: December 10, 2018; Published: December 18, 2018

*Corresponding author: Ahmed A Elmassry, Department of Ophthalmology, Alexandria University, Alexandria, Egypt

\begin{abstract}
Trichomegaly is defined as changes in eyelashes characteristics. In ophthalmology, the condition is commonly seen in glaucomatous patients receiving prostaglandin analogues eyedrops. In this report, we describe a rarely reported condition of a single eyelash changes of a 64 years old female patient on beta-blocker eye drops only with a single slightly less pigmented and extremely long eyelash at her left upper eyelid with no other associated changes in eyelid first noticed two weeks prior to presentation. The condition is medically unreported but once, as many practitioners consider it insignificant though whether it has other associations yet to be known.
\end{abstract}

\section{Introduction}

Trichomegaly is a condition where eyelashes are increased either in length, curling, thickness, pigmentation or any combination of them. Causes of the condition includes congenital, pharmacological or acquired disorders. In ophthalmology practice is a very common finding with patients on treatment of glaucoma using prostaglandin analogues. All the previous causes generally are associated with generalized trichomegaly, in this report we present a rare case of a single eyelash changes [1].

\section{Case Presentation}

A 64-years old female patient on a regular follow up for monitoring intraocular pressure. Her intraocular pressure is being controlled by beta - blockers eye drops only since she was diagnosed year and a half ago. She was diagnosed with diabetes mellitus type II eight months ago and receiving oral antiglycemic treatment (Metformin) on her last follow up, the patient complained of a long lash shadowing the vision of her left eye first noticed two weeks earlier.

Examination of the patient showed normal eye-lashes pattern except for a single long eye lash of the upper left eyelid measuring about $3.5 \mathrm{~cm}$ in length (Figure 1-3). The lash was slightly less pigmented than the adjacent lashes. With normal skin of eye lid margin and no visible lesions or skin changes. Other ophthalmological examination findings were unremarkable. Further history details were collected regarding similar condition in her family, any newly introduce systemic or local medications, use of new cosmetic materials or irritants, all were absent.

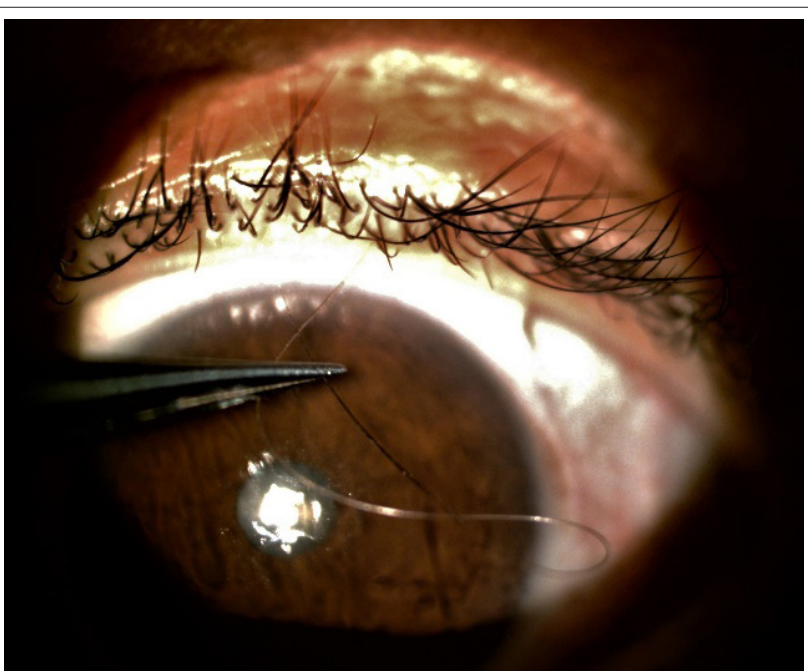

Figure 1: Before removal of the lash. 


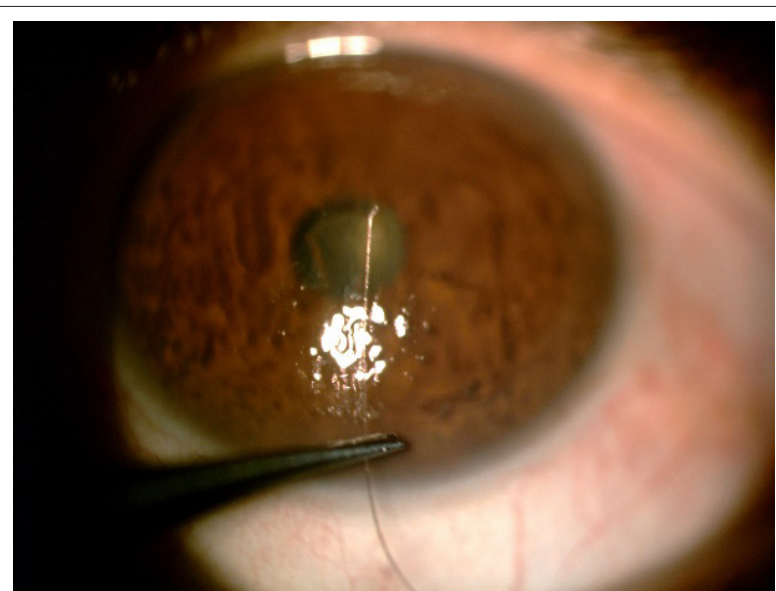

Figure 2: The removed eyelash root.

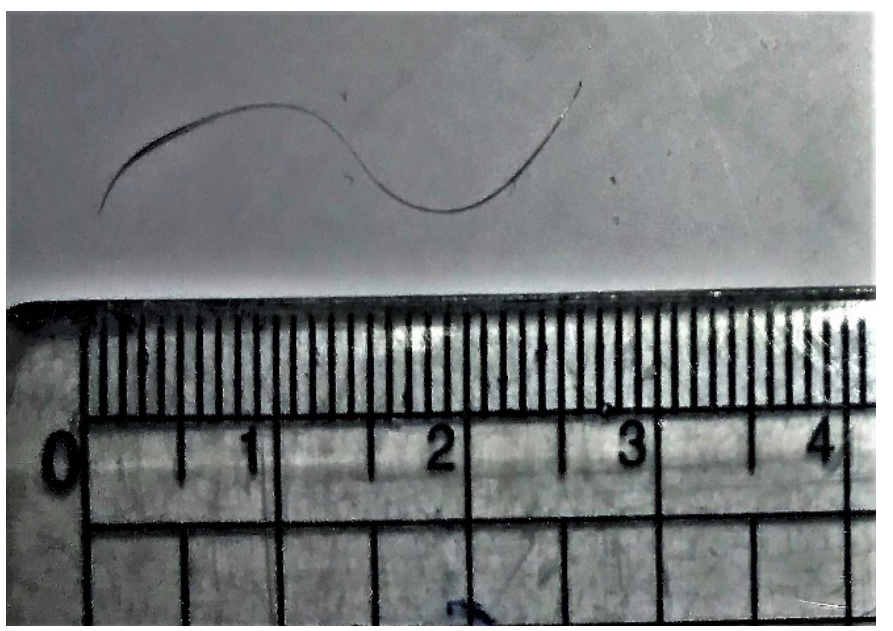

Figure 3: Crude measurement of the eyelash.

Changes in eyelashes length, pigmentation or curling is widely described in multiple conditions. Looking back at previous literature one can easily find multiple sources discussing trichomegaly causes. It is either:

a) Congenital as in Oliver-McFarlane syndrome and Cornelia de Lange syndrome.

b) Acquired conditions associated with eyelash trichomegaly as in alopecia areata and connective tissue disorders.

c) As a side effect of medications as topical prostaglandin analogues and epidermal growth factor receptors [1].

However, none of the previous causes have been reported with a single isolated eyelash changes in fact they affect the whole row of eyelashes equally and a more specified search only resulted in one case report presenting a young 9-year-old girl similar to our patient with no known possible cause or causative agent [2].
On the other hand, public online search was more fruitful and yielded multiple results regarding similar conditions on nonmedical video streaming or forum sites and Q \& A web pages.

\section{Conclusion}

In conclusion, the case in hand might be regarded rare considering that similar cases are rarely reported though this is just the tip of ice-berg as the public reported significantly bigger number of cases to be considered rare. This might be due to the fact that many ophthalmologists or dermatologist would consider it an insignificant finding due to lack of associated alarming history or diseases. Whether this sign is related to a specific condition is yet to be known.

\section{References}

1. Kaur S, Mahajan BB (2015) Eyelash trichomegaly. Indian J Dermatol 60(4): 378-380.

2. Bernabó JL, Baliu C, Navarra E, Ferrando J (2015) Isolated long white eyelash: An underrecognized trichologic finding. Int J Trichology 7(2): 84-85. 
This work is licensed under Creative Commons Attribution 4.0 License DOI: 10.19080/JOJCS.2018.09.555765
Your next submission with Juniper Publishers will reach you the below assets

- Quality Editorial service

- Swift Peer Review

- Reprints availability

- E-prints Service

- Manuscript Podcast for convenient understanding

- Global attainment for your research

- Manuscript accessibility in different formats

( Pdf, E-pub, Full Text, Audio)

- Unceasing customer service

Track the below URL for one-step submission

https://juniperpublishers.com/online-submission.php 